\title{
44. DATA REPORT: GEOCHEMISTRY OF VOLCANIC ASHES RECOVERED FROM HOLE 887A ${ }^{1}$
}

\author{
L.-Q. Cao, ${ }^{2}$ R.J. Arculus, ${ }^{2,3}$ and B.C. McKelvey ${ }^{2}$
}

\begin{abstract}
A total of 25 samples from 82 ash layers interbedded with middle Miocene to recent diatomaceous (variably calcareous) oozes and silty clays overlying Oligocene igneous basement was recovered from Ocean Drilling Program Hole 887A on the Patton-Murray seamount platform in the Gulf of Alaska, northeast Pacific. The ashes consist predominantly of elongate $(\approx \geq 5$ to $\approx<150 \mu \mathrm{m})$, tubular, and bubble-wall fragments probably derived from plinian eruption cloud fallout. Major element compositions determined by electron microprobe analysis of individual vitric shards are tholeiitic and bimodal, with predominant medium-K andesite and medium- to high- $\mathrm{K}$ rhyolite groups. There is no evidence from this sample set for consistent temporal geochemical changes. High $\mathrm{Ba} / \mathrm{Nb}$ and $\mathrm{Sm} / \mathrm{Ti}$ of these ash samples are similar to island-arc magmas in general. Chondrite-normalized La of 40 to $100, \mathrm{Yb}$ of 15 to 30 , and $\mathrm{La} / \mathrm{Yb}$ of about 2 to 3 are similar to tholeiitic volcanic rock series of the Aleutian arc. A major increase in the number of ash layers with depth in the core occurs interlayered with sediments younger than $2.7 \mathrm{Ma}$.
\end{abstract}

\section{INTRODUCTION}

Initial analytical results are presented here of an ongoing geochemical study of volcanic ash layers interlayered with middle Miocene to Quaternary sediments, which were recovered from Ocean Drilling Program (ODP) Hole $887 \mathrm{~A}\left(54^{\circ} 22^{\prime} \mathrm{N}, 148^{\circ} 27^{\prime} \mathrm{W}\right)$ in the Gulf of Alaska, overlying the Patton-Murray platform (Fig. 1). Hole 887A is located $\sim 2600 \mathrm{~km}$ from the Aleutian-Alaskan island arc. Although the prevailing low-altitude winds are unlikely to have transported ash to the south of this arc system, we know that major plinian eruptions can distribute ash in directions that oppose the low-altitude wind circulation (Carey and Sigurdsson, 1980). Furthermore, Cambray et al. (1993) have shown that representative records of activity can be obtained over time periods of $100 \mathrm{ka}$ on either side of island-arc systems, albeit moderated in terms of total thickness accumulations. We note that the thickness of the individual ash layers at Site 887 is generally $\leq 10 \mathrm{~cm}$ compared with $\leq 70 \mathrm{~cm}$ thick at Deep Sea Drilling Project (DSDP) Site $183\left(52^{\circ} 34^{\prime} \mathrm{N}, 161^{\circ} 12^{\prime} \mathrm{W}\right)$ (Creager, Scholl, et al., 1973) in the western Gulf of Alaska, which is located at about 150 $\mathrm{km}$ from the active subaerial arc. At both sites, the maximum thickness of individual ash layers is significantly less than the $\leq 250-\mathrm{cm}$ thick layers recovered from the Detroit Seamount sites (882-884) located some $600 \mathrm{~km}$ off the coast of Kamchatka.

We examine the first-order major and trace element compositional changes represented by these ashes during some $15 \mathrm{Ma}$ of arc history. Unfortunately, drilling did not recover volcanic ashes bracketing the period of consumption of the Kula Ridge at $\sim 30$ Ma beneath the Aleutian arc.

\section{PREVIOUS STUDIES}

The petrogenesis of the Aleutian arc system has been the subject of intensive investigations over the past $30 \mathrm{yr}$, since the pioneering studies by Coats (1962). There have been vigorous debates concerning the origins of the primary basalt (and andesite) magmas involved (Marsh and Carmichael, 1974; Kay, 1978; Baker and Eggler, 1983; Myers et al., 1985; Brophy and Marsh, 1986; Nye and Reid, 1986;

\footnotetext{
${ }^{1}$ Rea, D.K., Basov, I.A., Scholl, D.W., and Allan, J.F. (Eds.), 1995. Proc. ODP, Sci. Results, 145: College Station, TX (Ocean Drilling Program).

${ }^{2}$ Department of Geology and Geophysics, University of New England, Armidale, NSW 2351. Australia.

${ }_{3}$ Present address: Department of Geology, Australian National University, Canberra, ACT 0200, Australia.
}

Gust and Perfit, 1987; Myers, 1988; Brophy, 1989), the contributions of different source components, parameters that might control the occurrence of tholeiitic vs. calcalkaline fractionation trends (Kay et al., 1982; Morris and Hart, 1983; Kay and Kay, 1985; Myers et al., 1985; Singer and Myers, 1990; Miller et al., 1992), and the evolution of individual volcanic centers (Nye and Turner, 1990; Romick et al., 1990; Singer et al., 1992). The arc is composed for the most part of a single, narrowly distributed but segmented (Marsh, 1979; Kay et al., 1982; Geist et al., 1988; Singer and Myers, 1990) magmatic trace with only minor development of across-strike, alkalic volcanism.

Studies of the distal record of volcanic activity of the Aleutian arc have previously centered on DSDP Sites 178 and 183 in the Gulf of Alaska (e.g., Scheidegger and Kulm, 1975; Scheidegger et al., 1980). Previous studies have claimed that the composition of the volcanic rocks erupted throughout the Alaskan Peninsula and Aleutians during the Cenozoic, has changed through time (Scheidegger and Kulm, 1975; Edsall, 1976; Scheidegger et al., 1980). The primary observations are (1) that ashes become more silicic through to the Quaternary; (2) an evolution claimed by Edsall (1976) from tholeiitic to andesitic composition during the past $8 \mathrm{Ma}$, although the other authors cited argue there is no evidence for consistent secular variations in composition; noting however (3), that there are periods when either calcalkaline or tholeiitic magmas predominate. In the case of Site 178, a cyclic variation of $\mathrm{SiO}_{2}$ content through time was noted.

\section{STRATIGRAPHY AND LITHOLOGY}

In Table 1, the summary of the stratigraphic and lithologic characteristics of the ash layers from Hole $887 \mathrm{~A}$ lists the occurrences of all the ash layers reported in the Initial Reports volume (numbered from shallow to deep), identifies the layers sampled for geochemical analysis with a University of New England (UNE) number used in the other tables to identify specific ash layers, and reports ages for the ash layers determined by interpolation of the shipboard micropaleontology, magnetostratigraphy and the calculated sediment mass accumulation rates from Rea, Basov, Janecek, Palmer-Julson, et al. (1993), thickness of ash layers, dimensions of vitric shards, standard (Munsell) color estimated by us for the clay-free, dried, analyzed ash samples, Munsell colors (where reported by the shipboard scientists) for ash layers in the wet cores, volcanic rock type based on our major element analyses, and the nature of the lithologies bounding the ashes.

Rea, Basov, Janecek, Palmer-Julson, et al. (1993) identified a major increase in the number and thickness of the ash layers in sediments younger than about $2.7 \mathrm{Ma}$, a paucity of layers in sediments between $\approx 5$ and $7.5 \mathrm{Ma}$, and few ash layers in older sediments. 

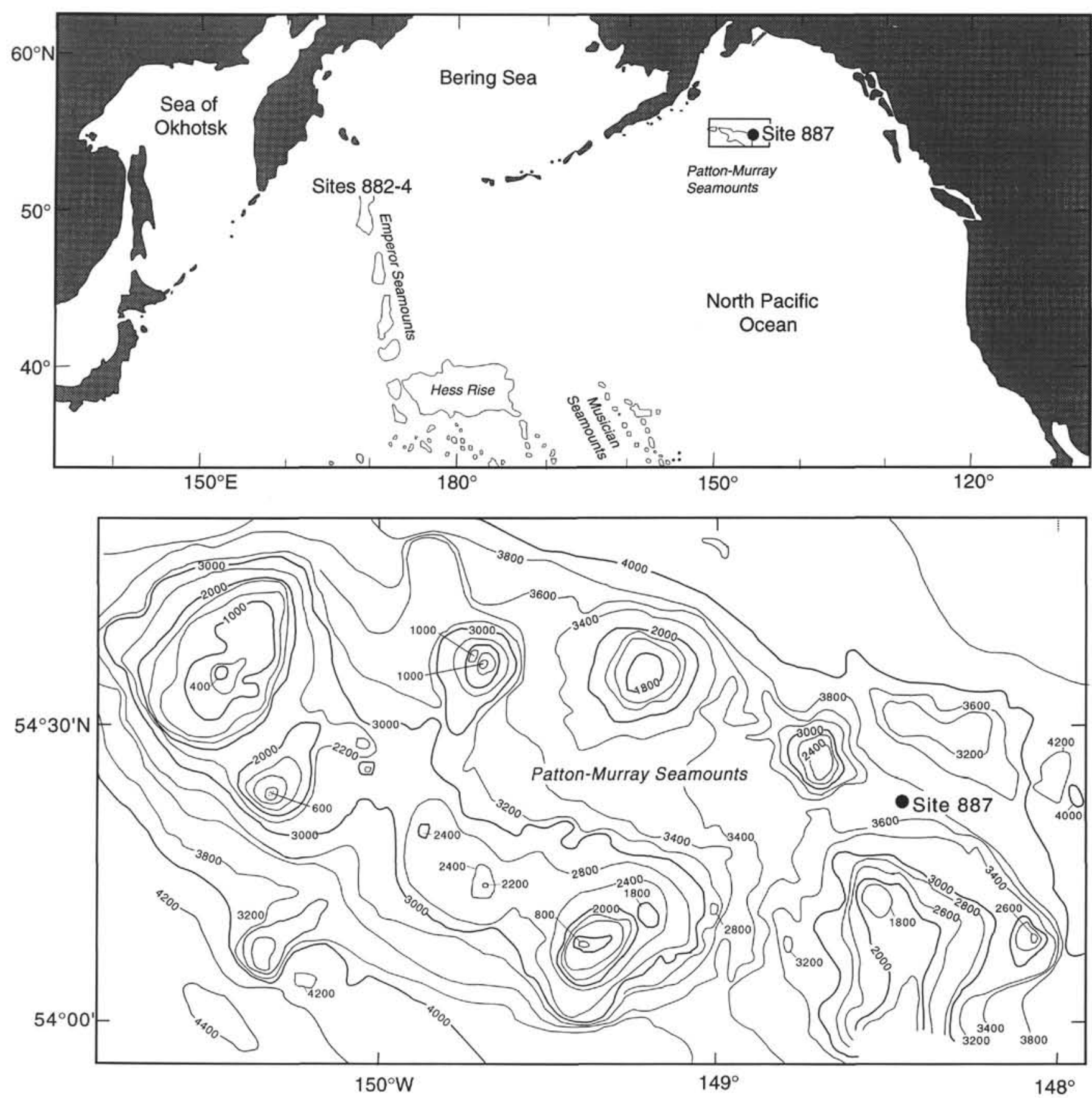

Figure 1. Index map of the North Pacific Ocean indicating the general location of Site 887 and detailed local bathymetry (depths in meters).

\section{ANALYTICAL PROCEDURES}

At the UNE, all of the samples were examined under a petrographic microscope to determine the morphologies and sizes of the shards, noting in particular those layers containing a sufficient number of shards large enough to analyze (at least $10 \mu \mathrm{m}$ in diameter) by electron microprobe (EMP) and any significant organic and clay contamination. We did not sieve any of the samples. Ash samples were carefully washed with distilled water and dried at $105^{\circ} \mathrm{C}$, affixed in an epoxy mounting ring, polished, and carbon coated.

The major element chemical compositions of individual vitric shards were obtained at the UNE using a JEOL Model JSM35 EMP with a KEVEX Si-Li energy dispersive spectrometer (EDS). Nine elements ( $\mathrm{Si}, \mathrm{Ti}, \mathrm{Al}, \mathrm{Fe}, \mathrm{Mn}, \mathrm{Mg}, \mathrm{Ca}, \mathrm{K}, \mathrm{Na}$ ) were analyzed. The shards analyzed appear pristine, with no sign of hydration or clay formation. Standard natural and synthetic glasses from the Smithsonian Institution were analyzed concurrently, with excellent agreement between our analyses and the published values. Furthermore, comparisons of ash analyses obtained with this instrument and wavelength-dispersive EMP(Camebax) at the University of Michigan (Arculus and Bloomfield, 1992) and the Australian National University are in excellent agreement, although we prefer the EDS system for minimizing sample damage and $\mathrm{Na}$ loss from hydrous, $\mathrm{SiO}_{2}$-rich glasses. Operating conditions were $15-\mathrm{kV}$ accelerating voltage, $10-\mathrm{nA}$ beam current, and 100 -s count time.

We selected 16 of the 25 ash layers for bulk analysis of 36 trace elements by inductively coupled plasma source mass spectrometry (ICP-MS; using a VG PlasmaQuad PQ2+) at Monash University. Our selection criteria for the application of this analytical technique were 
Table 1. Stratigraphic and lithologic characteristics of volcanic ash layers from Hole 887A.

\begin{tabular}{|c|c|c|c|c|c|c|c|c|}
\hline $\begin{array}{l}\text { UNE } \\
\text { number }\end{array}$ & $\begin{array}{l}\text { Age } \\
\text { (Ma) }\end{array}$ & $\begin{array}{l}\text { Depth } \\
\text { (mbsf) }\end{array}$ & $\begin{array}{l}\text { Thickness } \\
\text { (cm) }\end{array}$ & $\begin{array}{c}\text { Size of } \\
\text { vitric shard } \\
(0.01 \mathrm{~mm})\end{array}$ & $\begin{array}{c}\text { Color } \\
\text { (dry sample) }\end{array}$ & $\begin{array}{c}\text { Color } \\
\text { (shipboard estimate) }\end{array}$ & Composition & Lithology \\
\hline & 0.01 & 1.5 & 1 & - & - & - & - & Diatom clay and diatom ooze \\
\hline \multirow[t]{6}{*}{155} & 0.02 & 1.8 & 5 & $1 \times 5$ & Light gray $(2.5 Y 7 / 1)$ & - & Rhyolite & Diatom clay and diatom ooze \\
\hline & 0.03 & 3 & 6 & - & - & - & - & Diatom clay and diatom ooze \\
\hline & 0.04 & 3.5 & 3 & - & - & - & - & Diatom clay and diatom ooze \\
\hline & 0.04 & 5.9 & 3 & - & - & - & - & Diatom clay and diatom ooze \\
\hline & 0.05 & 6.8 & 5 & - & - & - & - & Diatom clay and diatom ooze \\
\hline & 0.09 & 10.5 & 1 & - & - & - & - & Diatom clay and diatom ooze \\
\hline 156 & 0.1 & 10.7 & 18 & $2 \times 10$ & Light gray $(2.5 \mathrm{Y} 7 / 1)$ & - & Rhyolite & Diatom clay and diatom ooze \\
\hline \multirow{4}{*}{157} & 0.11 & 11.1 & 9 & $2 \times 3$ & Yellowish gray $(2.5 Y$ 4/1) & - & - & Diatom clay and diatom ooze \\
\hline & 0.13 & 11.8 & 3 & - & — & - & - & Diatom clay and diatom ooze \\
\hline & 0.14 & 12.3 & 3 & - & - & - & - & Diatom clay and diatom ooze \\
\hline & 0.14 & 12.4 & 1 & - & - & - & - & Diatom clay and diatom ooze \\
\hline \multirow[t]{13}{*}{158} & 0.16 & 12.8 & 12 & $1 \times 5$ & Light gray (2.5Y 8/1) & - & Rhyolite & Diatom clay and diatom ooze \\
\hline & 0.18 & 13.3 & 2 & - & — & - & - & Diatom clay and diatom ooze \\
\hline & 0.19 & 13.5 & 2 & - & - & - & - & Diatom clay and diatom ooze \\
\hline & 0.22 & 13.7 & 3 & - & - & - & - & Diatom clay and diatom ooze \\
\hline & 0.29 & 14.7 & 2 & - & - & - & - & Diatom clay and diatom ooze \\
\hline & 0.31 & 16.4 & 13 & - & - & - & - & Diatom clay and diatom ooze \\
\hline & 0.32 & 17.2 & 3 & - & - & - & - & Diatom clay and diatom ooze \\
\hline & 0.33 & 19.5 & 4 & - & - & - & - & Diatom clay and diatom ooze \\
\hline & 0.35 & 20.7 & 2 & - & - & - & - & Diatom clay and diatom ooze \\
\hline & 0.36 & 23.5 & 1 & - & - & - & - & Diatom clay and diatom ooze \\
\hline & 0.37 & 24.5 & 3 & - & - & - & - & Diatom clay and diatom ooze \\
\hline & 0.38 & 25.5 & 3 & - & - & - & - & Diatom clay and diatom ooze \\
\hline & 0.39 & 26.6 & 1 & - & - & - & - & Diatom clay and diatom ooze \\
\hline \multirow[t]{4}{*}{159} & 0.42 & 29.7 & 4 & $6 \times 12$ & Dark grayish yellow $(2.5 \mathrm{Y} 4 / 2)$ & - & - & Diatom clay and diatom ooze \\
\hline & 0.5 & 34.3 & 3 & - & — & - & - & Diatom clay and diatom ooze \\
\hline & 0.52 & 34.4 & 1 & - & - & - & - & Diatom clay and diatom ooze \\
\hline & 0.58 & 37.2 & 2 & - & - & - & - & Diatom ooze with clay \\
\hline 160 & 0.6 & 38.8 & 4 & $0.5 \times 2$ & Light gray $(2.5 Y 7 / 1)$ & - & Rhyolite & Diatom ooze with clay \\
\hline \multirow[t]{3}{*}{161} & 0.61 & 39.5 & 3 & $5 \times 10$ & Yellowish gray $(2.5 \mathrm{Y}$ 4/1) & - & Rhyolite & Diatom ooze with clay \\
\hline & 0.63 & 40.5 & 1 & - & - -2 & - & - & Diatom ooze with clay \\
\hline & 0.64 & 40.7 & 2 & - & - & - & - & Diatom ooze with clay \\
\hline 162 & 0.76 & 46.3 & 2 & $3 \times 7$ & Yellowish gray (2.5Y 5/1) & - & Rhyolite & Clay and diatom ooze \\
\hline 163 & 0.78 & 48.7 & 7 & $1 \times 6$ & Dark grayish yellow $(2.5 Y 5 / 2)$ & - & Rhyolite & Clay and diatom ooze \\
\hline & 0.79 & 49.7 & 1 & - & — & - & - & Clay and diatom ooze \\
\hline & 0.81 & 50.3 & 1 & - & - & - & - & Clay and diatom ooze \\
\hline 164 & 0.85 & 52.5 & 1 & $6 \times 8$ & Yellowish gray (2.5Y 5/1) & - & - & Clay and diatom ooze \\
\hline & 0.88 & 54.2 & 1 & - & - & - & - & Clay and diatom ooze \\
\hline & 0.89 & 54.4 & 5 & - & - & - & - & Clay and diatom ooze \\
\hline & 0.91 & 56.4 & 1 & - & - & - & - & Clay with quartz \\
\hline & 0.92 & 56.6 & 2 & - & - & Black (2.2GY $2.7 / 0.6)$ & - & Clay with quartz \\
\hline & 0.93 & 56.9 & 4 & - & - & Black $(2.2 \mathrm{GY} 2.7 / 0.6)$ & - & Clay with quartz \\
\hline 165 & 1 & 61.2 & 6 & - & Yellowish gray (2.5Y 4/1) & Black (2.2GY $2.7 / 0.6)$ & - & Clay with quartz \\
\hline 166 & 1.15 & 63 & 7 & $1 \times 5$ & Yellowish gray $(2.5$ Y $6 / 1)$ & Black (2.2GY $2.7 / 0.6)$ & - & Clay with quartz \\
\hline & 1.2 & 64.8 & 2 & - & - & Brown (3.9Y $2.7 / 1.0)$ & - & Clay with quartz \\
\hline & 1.3 & 65.6 & 3 & - & - & Black (0.8GY $2.9 / 0.5)$ & - & Clay with quartz \\
\hline & 1.4 & 66.3 & 2 & - & - & Black $(0.8 \mathrm{GY} 2.9 / 0.5)$ & - & Clay with quartz \\
\hline 167 & 1.55 & 67.7 & 3 & - & Light gray (2.5Y $8 / 1)$ & Black (0.8GY 2.9/0.5) & - & Clay with quartz \\
\hline & 1.6 & 68.1 & 3 & - & - & Light gray $(2.2 Y 4.8 / 0.8)$ & - & Clay with quartz \\
\hline & 1.7 & 70 & & - & - & Black $(0.8 \mathrm{GY} 2.9 / 0.5)$ & - & Clay with quartz \\
\hline & 1.8 & 72.5 & & - & - & - & - & Clay with quartz \\
\hline & 1.9 & 72.8 & 5 & - & - & - & - & Clay with quartz \\
\hline & 2 & 82.9 & 2 & - & - & Black (0.8GY $2.9 / 0.5)$ & - & Clay with ash, clay and diatom ooze \\
\hline 168 & 2.3 & 84.1 & 6 & $3 \times 5$ & Yellowish gray $(2.5 Y 4 / 1)$ & Gray $(3.8 Y 4.0 / 1.2)$ & Basaltic andesite & Clay with ash, clay and diatom ooze \\
\hline & 2.35 & 84.8 & 11 & - & - $\quad$ ond & Black (4.8Y $1.8 / 0.7)$ & - & Clay with ash, clay and diatom ooze \\
\hline & 2.4 & 86.5 & 3 & - & - & Black $(4.8 Y$ 1.8/0.7) & - & Clay with ash, clay and diatom ooze \\
\hline & 2.5 & 87.5 & 1 & - & - & Brown $(1.6 Y 3.3 / 2.1)$ & - & Clay with ash, clay and diatom ooze \\
\hline & 2.6 & 88.2 & $i$ & - & - & Gray $(3.8 Y 4.0 / 1.2)$ & - & Clay with ash, clay and diatom ooze \\
\hline & 2.65 & 88.5 & 5 & - & - & Gray (3.8Y 4.0/1.2) & - & Clay with ash, clay and diatom ooze \\
\hline 169 & 2.7 & 89.1 & 5 & $1 \times 5$ & Grayish yellow $(2.5 Y 6 / 2)$ & Gray $(3.8 Y 4.0 / 1.2)$ & Dacite-rhyolite & Clay with ash, clay and diatom ooze \\
\hline & 2.71 & 89.7 & 6 & - & - & Brown $(1.6 Y 3.3 / 2.1)$ & - & Clay with ash, clay and diatom ooze \\
\hline & 2.72 & 90.3 & 4 & - & - & Gray $(3.8 \mathrm{Y} 4.0 / 1.2)$ & - & Clay with ash, clay and diatom ooze \\
\hline 170 & 2.73 & 90.7 & 4 & $0.5 \times 4$ & Light gray $(2.5 \mathrm{Y} 7 / 1)$ & Black $(4.8 Y 1.8 / 0.7)$ & Dacite-rhyolite & Clay with ash, clay and diatom ooze \\
\hline & 2.79 & 93.5 & 7 & - & - & Gray $(3.8 Y 4.0 / 1.2)$ & - & Diatom ooze \\
\hline 171 & 2.86 & 98.7 & 3 & $1 \times 7$ & Light gray $(2.5 Y 7 / 1)$ & Black(1.1Y 3.3/0.6) & Rhyolite & Diatom ooze \\
\hline 172 & 2.87 & 99.1 & 3 & $1 \times 5$ & Light gray $(2.5 \mathrm{Y} 7 / 1)$ & Brown(2.0Y 4.2/0.9) & Rhyolite & Diatom ooze \\
\hline 173 & 3.7 & 114.3 & 10 & $1 \times 15$ & Yellowish gray $(2.5 \mathrm{Y} 6 / 1)$ & Brown(2.0Y 4.2/0.9) & Rhyolite & Diatom ooze \\
\hline 174 & 3.75 & 116.7 & 2 & $1 \times 3$ & Light gray $(2.5 \mathrm{Y} 7 / 1)$ & $\operatorname{Red}(8.7 \mathrm{R} 3.1 / 0.8)$ & Rhyolite & Diatom ooze \\
\hline & 4 & 123.9 & 6 & - & - & Brown(4.0Y 2.7/0.9) & - & Diatom ooze \\
\hline 175 & 4.1 & 124.7 & 11 & $2 \times 3$ & Yellowish gray $(2.5 \mathrm{Y} 6 / 1)$ & Black(0.8RP 2.6/0.7) & Andesite & Diatom ooze \\
\hline & 4.3 & 127.1 & 3 & - & - & Black(0.8RP 2.6/0.7) & - & Diatom ooze \\
\hline & 4.7 & 135.7 & 4 & - & - & Black & - & Diatom ooze \\
\hline 176 & 4.85 & 142.9 & 4 & $1 \times 5$ & Light gray $(2.5 Y 7 / 1)$ & Light gray & - & Diatom ooze \\
\hline 177 & 4.88 & 143.8 & 4 & $1 \times 4$ & Light gray $(2.5 \mathrm{Y} 7 / 1)$ & Dark brown (9.9YR 2.4/1.8) & Dacite-rhyolite & Diatom ooze \\
\hline 178 & 8.85 & 214.2 & 6 & $1 \times 5$ & Yellowish gray (2.5Y 6/1) & Dark brown (9.9YR 2.4/1.8) & Basaltic andesite & Nannofossil ooze \\
\hline 179 & 10.4 & 230.7 & 9 & $2 \times 10$ & Yellowish gray $(2.5 \times 6 / 1)$ & — & Andesite - rhyolite & Nannofossil ooze \\
\hline 180 & 14.5 & 256.9 & 15 & $2.5 \times 15$ & - & Dark brown $(9.0$ YR $3.2 / 1.7)$ & Rhyolite & Nannofossil ooze \\
\hline
\end{tabular}

to obtain a spread of ages of ash layers; to avoid clay, diatom, and carbonate contamination as much as possible; and to concentrate on those layers that appeared to be relatively homogenous in terms of major element chemistry as resolved by EMP analysis.

Sample preparation involved digestion of $0.1 \pm 0.03 \mathrm{~g}$ of distilled water-washed ash sample for 24 to $48 \mathrm{hr}$ in screw-top Teflon bombs at $100^{\circ}-120^{\circ} \mathrm{C}$ in a mixture of distilled $\mathrm{HF}(4 \mathrm{~mL})$ and distilled $\mathrm{HNO}_{3}(2$ $\mathrm{mL}$ ). Sample solutions were slowly dried (with heat lamps) and converted from fluorides to nitrates with additions of concentrated $\mathrm{HNO}_{3}$. Samples were then taken into solution with $50 \mathrm{~g}$ of $2 \% \mathrm{HNO}_{3}$ (made from sub-boiled, distilled concentrated $\mathrm{HNO}_{3}$ and $18.2 \mathrm{M} \Omega$ Millipore $\mathrm{H}_{2} \mathrm{O}$ ). Aliquots of this solution were run at a total dilution factor of 


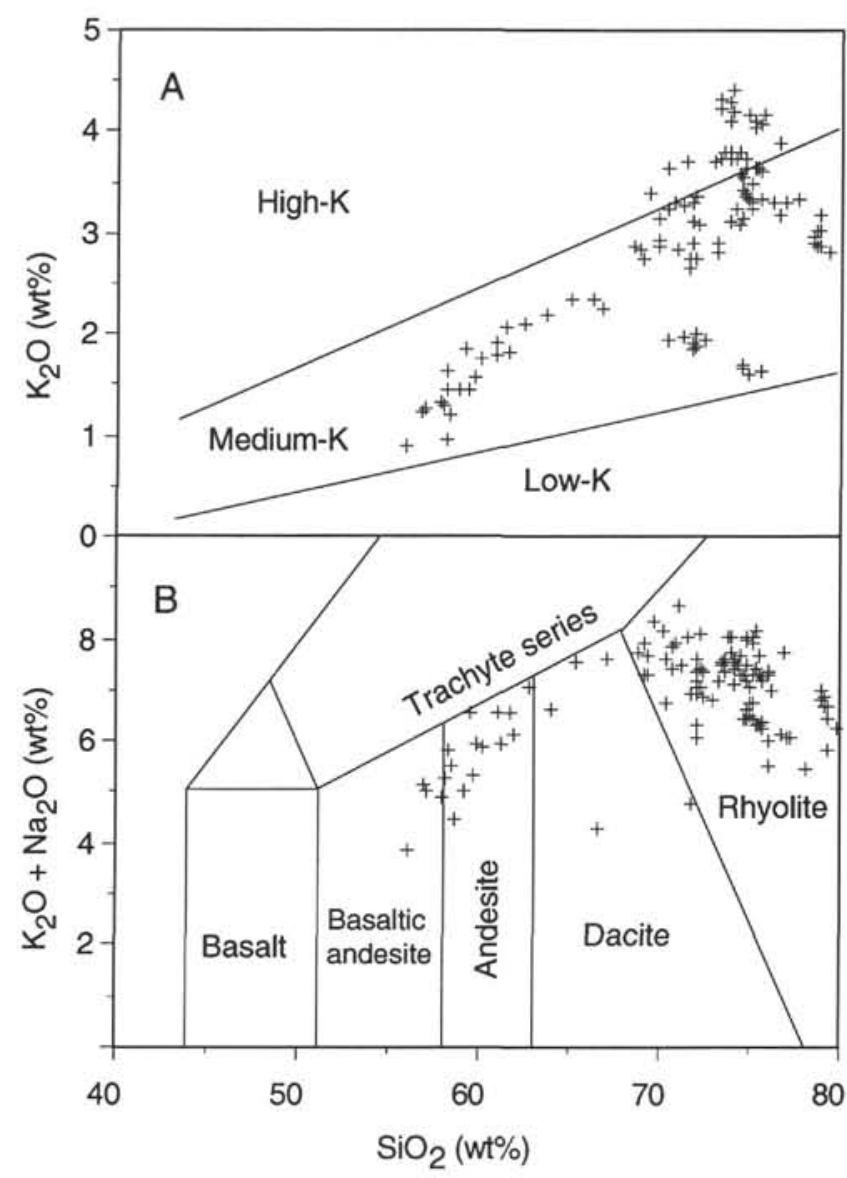

Figure 2. A. $\mathrm{K}_{2} \mathrm{O}$ vs. $\mathrm{SiO}_{2}$ for individual vitric shards from Hole $887 \mathrm{~A}$. Fields of low-, medium-, and high-K are from Gill (1981). B. Variation of $\left(\mathrm{K}_{2} \mathrm{O}+\right.$ $\mathrm{Na}_{2} \mathrm{O}$ ) vs. $\mathrm{SiO}_{2}$ for individual vitric shards from Hole $887 \mathrm{~A}$. Fields are from Le Bas et al. (1986).

$\approx 2000$. All samples were made up with $100 \mathrm{ppb}$ In to serve as an internal standard for drift correction. One analytical blank and five standard solutions (based on U.S. Geological Survey standard rocks) were typically prepared for each run. An initial calibration was performed using synthetic standards and finalized with a set of laboratory and international standards. Total analytical blanks are typically $<20 \mathrm{ppb}$ for most elements except for $\mathrm{Sc}, \mathrm{Cr}, \mathrm{Cu}$, and $\mathrm{Ni}$ (which are $<500 \mathrm{ppb}$ ). Errors are $\pm 15-20$ relative $\%$ for $\mathrm{Sc}, \mathrm{Ga}, \mathrm{Ge}, \mathrm{Pr}, \mathrm{Gd}$, Th, and U depending on abundances, $\pm 5-10$ relative $\%$ for the other rare earth elements (REE) and $\pm 3-15$ relative $\%$ for all other trace elements analyzed.

\section{RESULTS}

Representative major element analyses of individual vitric shards are listed in Table 2. The bulk analysis of selected ash layers based on the ICP-MS trace element analysis and calculated in the case of major elements from the average of the EMP analyses of individual shards is presented in Table 3 .

The composition spectrum of ash layers recovered from Hole $887 \mathrm{~A}$ ranges from medium- $\mathrm{K}$ basaltic andesite to medium- and high$\mathrm{K}$ rhyolite (Fig. 2). No low-K samples were found. Almost all of these samples are tholeiitic on the basis of Miyashiro's (1974) criterion (Fig. 3). An apparent bimodality of compositional distribution of the shards into either andesite or rhyolite groups is apparent in Figures 2 and 3, with minor occurrences of basaltic andesite and dacite compositions. It is not apparent from plots of composition vs. age (Fig. 4) that any regularities of secular change exist, including any trend towards increasingly silicic compositions with time.

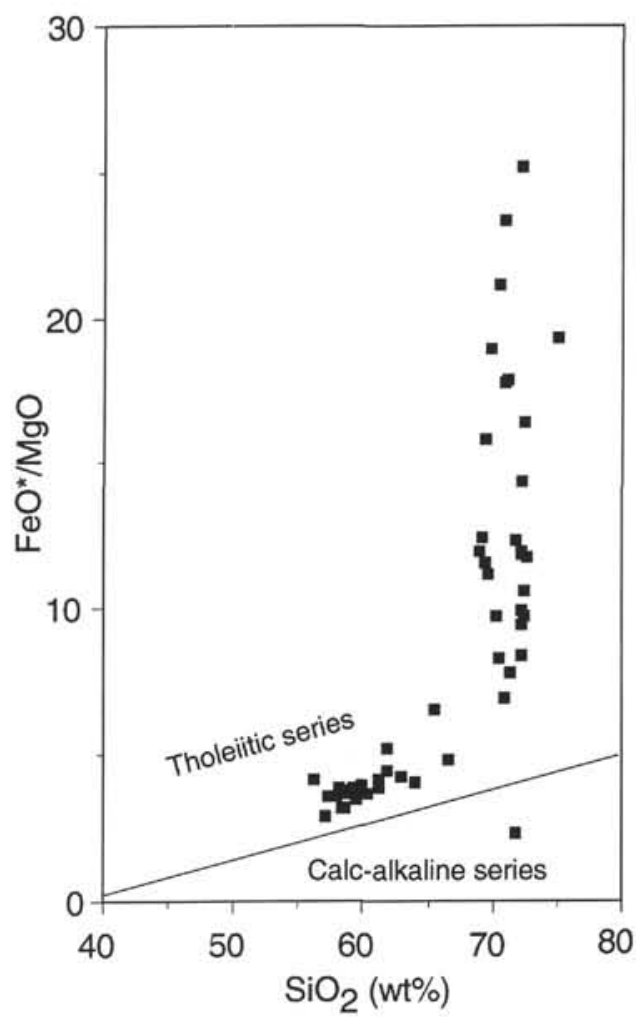

Figure 3. Variation of $\mathrm{FeO} * / \mathrm{MgO}$ vs. $\mathrm{SiO}_{2}$ of vitric shards from Hole $887 \mathrm{~A}$. The discriminant line between tholeiitic and calc-alkaline series of Miyashiro (1974) is shown.

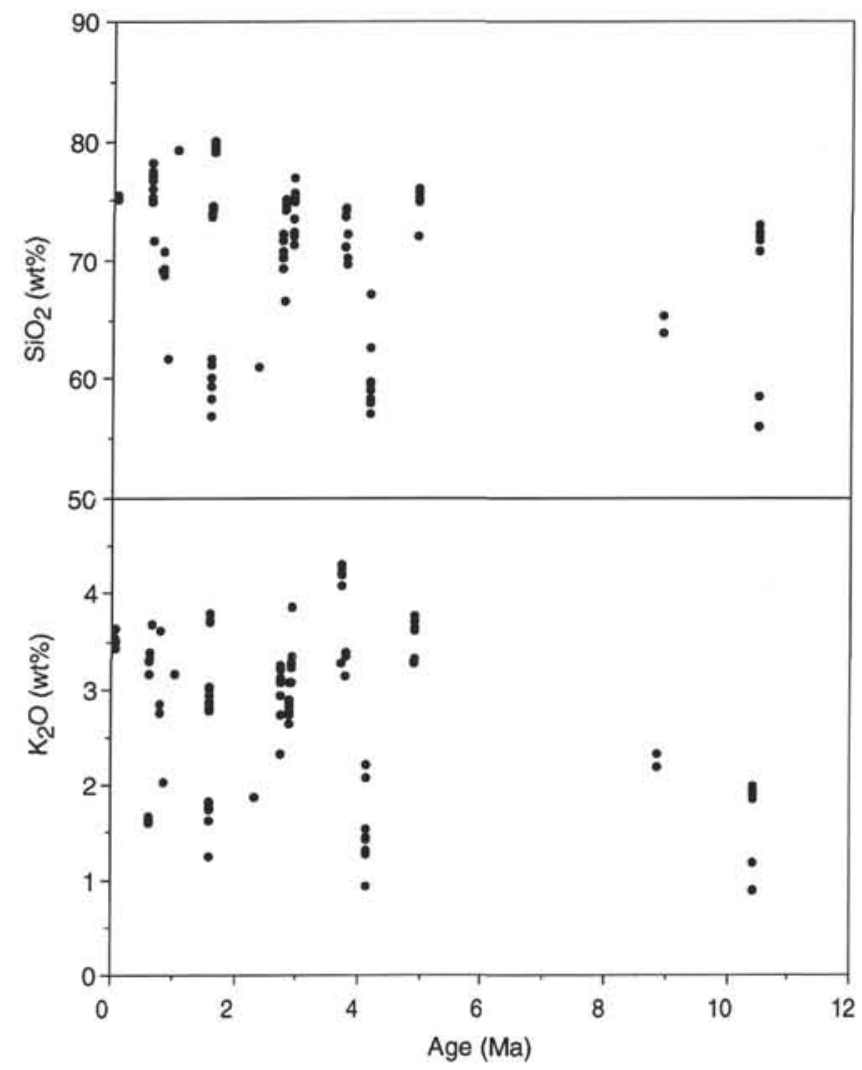

Figure 4. Variation of $\mathrm{SiO}_{2}$ and $\mathrm{K}_{2} \mathrm{O}$ as a function of age of individual vitric shards from Hole 887A. Ages were estimated from shipboard micropaleontology, magnetostratigraphy, and interpolations from the sediment mass-accumulation rate (see text). 
Representative chondrite-normalized rare earth element abundances are displayed in Figure 5. A more extended graphical comparison of the abundances of a range of trace elements of variable degrees of crystalline phase compatibility is shown in Figure 6. We note that the abundances of the REE in the majority of these ash samples are similar to those of tholeiitic series volcanic rocks of the Aleutians reported by, for example Kay (1977), with chondrite-normalized La of 40 to $100, \mathrm{Yb}$ of 15 to 30 , and La/Yb of about 2 to 3 . However, we also note that the chondrite-normalized $\mathrm{La} / \mathrm{Sm}$ of many of these ash samples $(\approx 2)$ exceeds that of the tholeiitic rocks of the Aleutian arc and is more similar to the $\mathrm{La} / \mathrm{Sm}$ fractionation claimed for the calcalkaline series by Kay (1977). For two of the ash layers (UNE numbers 164 and 165), the REE abundances are similar overall to the calcalkaline series recognized by Kay (1977). Finally, we note that the distinctively high $\mathrm{Ba} / \mathrm{Nb}$ and $\mathrm{Sm} / \mathrm{Ti}$ of the ashes from Site 887 (Fig. 6) are consistent with derivation from an arc magma source.

In summary, on the basis of major and trace element analysis of a representative set of ash layers recovered from Hole $887 \mathrm{~A}$, no consistent temporal changes in geochemistry of the sources involved can be discerned for the past $\sim 16 \mathrm{Ma}$. The range of major element compositions is bimodal with predominant medium- $\mathrm{K}$ andesite and mediumto high-K rhyolite groups. Almost all are tholeiitic on the basis of Miyashiro's (1974) criterion. Morphologies of the shards coupled with distinctively high $\mathrm{Ba} / \mathrm{Nb}$ and $\mathrm{Sm} / \mathrm{Ti}$ indicate derivation through plinian fallout from explosive eruptions of an island arc. A major increase in the number of ash layers occurs in sediments younger than $2.7 \mathrm{Ma}$.

\section{ACKNOWLEDGMENTS}

The support of David Rea for our involvement in this study is greatly appreciated, as is the diligence of the shipboard scientific party in providing representative samples. Our research was funded by a grant from the Australian Research Council. Peter Garlick and Rick Porter ensured that the EMP at UNE was available and functional. The tolerance and good service of Dr. David Lambert at the Monash ICP-MS facility is much appreciated. L.-Q. Cao was supported by OPRS and UNEOSS scholarships.

\section{REFERENCES}

Arculus, R.J., and Bloomfield, A.L., 1992. Major-element geochemistry of ashes from Sites 782, 784, and 786 in the Bonin forearc. In Fryer, P., Pearce, J.A., Stokking, L.B., et al., Proc. ODP, Sci. Results, 125: College Station, TX (Ocean Drilling Program), 277-292.

Baker, D.R., and Eggler, D.H., 1983. Fractionation paths of Atka (Aleutians) high-alumina basalts: constraints from phase relations. J. Volcanol. Geotherm. Res., 18:387-404.

Brophy, J.G., 1989. Can high-alumina arc basalt be derived from low-alumina arc basalt? Evidence from Kanaga island, Aleutian arc, Alaska. Geology, 17:333-336

Brophy, J.G., and Marsh, B.D., 1986. On the origin of high-alumina arc basalt and the mechanics of melt extraction. J. Petrol., 27:763-789.

Cambray, H., Cadet, J-P., and Pouclet, A., 1993. Ash layers in deep-sea sediments as tracers of arc volcanic activity: Japan and Central America as case studies. The Island Arc, 2:72-86.

Carey, S., and Sigurdsson, H., 1980. The Roseau ash: deep-sea tephra deposits from a major eruption on Dominica, Lesser Antilles arc. J. Volcanol. Geotherm. Res., 7:67-86.

Coats, R.R., 1962. Magma type and crustal structure in the Aleutian arc. In Macdonald, G.A., and Kuno, H. (Eds.), The Crust of the Pacific Basin. Geophys. Monogr., Am. Geophys. Union, 6:92-109.

Creager, J.S., Scholl, D.W., et al., 1973. Init. Repts. DSDP, 19: Washington (U.S. Govt. Printing Office).

Edsall, D.W., 1976. Trace elements in tephra as indicators of magmatic composition in the Aleutian arc. Geol. Soc. Am. Bull., 87:1269-1272.

Geist, E.L., Childs, J.R., and Scholl, D.W., 1988. The origin of summit basins of the Aleutian Ridge: implications for block rotation of an arc massif. Tectonics, 7:327-341.

Gill, J.B., 1981, Orogenic Andesites and Plate Tectonics: New York (SpringerVerlag).
Gust, D.A., and Perfit, M.R., 1987. Phase relations of a high-Mg basalt from the Aleutian island arc: implications for primary island arc basalts and high-Al basalts. Contrib. Mineral. Petrol., 97:7-18.

Kay, R.W., 1977. Geochemical constraints on the origin of Aleutian magmas. In Talwani, M., and Pittman, W.C. III (Eds.), Island Arcs, Deep Sea Trenches and Back Arc Basins: Am. Geophys. Union, Maurice Ewing Ser., $1: 229-242$.

1978. Aleutian magnesian andesites: melts from subducted Pacific ocean crust. J. Volcanol. Geotherm. Res., 4:117-132.

Kay, S.M., Kay, R.W., and Citron, G.P., 1982. Tectonic controls on tholeitic and calc-alkaline magmatism in the Aleutian arc. J. Geophys. Res., $87: 4051-4072$

Kay, S.M., and Kay, R.W., 1985. Role of crystal cumulates and the oceanic crust in the formation of the lower crust of the Aleutian arc. Geology, $13: 461-464$

Le Bas, M.J., Le Maitre, R.W., Streckeisen, A., and Zanettin, B., 1986. A chemical classification of volcanic rocks based on the total alkali-silica diagram. J. Petrol., 27:745-750.

Marsh, B.D., 1979. Island-arc volcanism. Am. Sci., 67:161-172.

Marsh, B.D., and Carmichael, I.S.E., 1974. Benioff Zone magmatism. J. Geophys. Res., 79:1196-1206.

Miller, D.M., Langmuir C.H., Doldstein, S.L. and Franks, A.L., 1992. The importance of parental magma composition of calc-alkaline and tholeiitic evolution: evidence from Umnak Island in the Aleutians. J. Geophys. Res., 97:321-345

Miyashiro, A., 1974. Volcanic rock series in island arcs and active continental margins. Am. J. Sci., 274:321-355.

Morris, J.D., and Hart, S.R., 1983. Isotopic and incompatible element constraints on the genesis of island arc volcanics from Cold Bay and Amak islands, Aleutians, and implications for mantle structure. Geochim. Cosmochim. Acta, 47:2015-2030.

Myers, J.D., 1988. Possible petrogenetic relations between low- and highMgO Aleutian basalts. Geol. Soc. Am. Bull., 100:1040-1053.

Myers, J.D., Marsh, B.D., and Sinha, A.K., 1985. Strontium isotopic and selected trace element variations between two Aleutian volcanic centers (Adak and Atka): implications for the development of arc volcanic plumbing systems. Contrib. Mineral. Petrol., 91:221-234.

Nye, C.J., and Reid, M.R., 1986. Geochemistry of primary and least fractionated lavas from Okmok volcano, central Aleutians: implications for magmagenesis. J. Geophys. Res., 91:10271-10287.

Nye, C.J., and Turner, D.L., 1990. Petrology, geochemistry and age of the Spurr volcanic complex, eastern Aleutian arc. Bull. Volcanol., 52:205-226.

Rea, D.K., Basov, I.A., Janecek, T.R., Palmer-Julson, A., et al., 1993. Proc. ODP, Init. Repts., 145: College Station, TX (Ocean Drilling Program).

Romick, J.D., Perfit, M.R., Swanson, S.E. and Shuster, R.D., 1990. Magmatism in the eastern Aleutian arc: temporal characteristic of igneous activity on Akutan Island. Contrib. Mineral. Petrol., 104:700-720.

Scheidegger, K.F., Corliss, J.B., Jezek, P.A., and Ninkovich, D., 1980. Composition of deep-sea ash layers derived from north Pacific volcanic arcs: variations in time and space. J. Volcanol. Geotherm. Res., 7:107-137.

Scheidegger, K.F., and Kulm, L.D., 1975. Late Cenozoic volcanism in the Aleutian arc: information from ash layers in the northeastern Gulf of Alaska. Geol. Soc. Am. Bull., 86:1407-1412.

Singer, B.S., and Myers, J.D., 1990. Intra-arc extension and magmatic evolution in the central Aleutian arc, Alaska. Geology, 18:1050-1053,

Singer, B.S., Myers, J.D., and Frost, C.D., 1992. Mid-Pleistocene basalt from the Seguam volcanic center, central Aleutian arc, Alaska: local lithospheric structures and source variability in the Aleutian arc. J. Geophys. Res., 97:4561-4578.

Sun, S.-S., and McDonough, W.F., 1989. Chemical and isotopic systematics of oceanic basalts: implications for mantle composition and processes. In Saunders, A.D., and Norry, M.J. (Eds.), Magmatism in the Ocean Basins. Geol. Soc. Spec. Publ. London, 42:313-345.

\footnotetext{
-Abbreviations for names of organizations and publications in ODP reference lists follow the style given in Chemical Abstracts Service Source Index (published by American Chemical Society).
}

Date of initial receipt: 26 April 1994

Date of acceptance: 31 October 1994 Ms 145SR-127 
Table 2. Representative analyses of vitric shards from Hole 887A.

\begin{tabular}{|c|c|c|c|c|c|c|c|c|c|c|c|c|c|c|c|}
\hline $\begin{array}{l}\text { UNE number: } \\
\text { Core, section: } \\
\text { Interval }(\mathrm{cm}) \text { : }\end{array}$ & $\begin{array}{c}155 \\
1 \mathrm{H}-2 \\
36-37 \\
\end{array}$ & $\begin{array}{c}155 \\
1 \mathrm{H}-2 \\
36-37\end{array}$ & $\begin{array}{c}155 \\
1 \mathrm{H}-2 \\
36-37\end{array}$ & $\begin{array}{c}155 \\
1 \mathrm{H}-2 \\
36-37 \\
\end{array}$ & $\begin{array}{c}155 \\
1 \mathrm{H}-2 \\
36-37 \\
\end{array}$ & $\begin{array}{c}156 \\
2 \mathrm{H}-3 \\
117-118 \\
\end{array}$ & $\begin{array}{c}156 \\
2 \mathrm{H}-3 \\
117-118 \\
\end{array}$ & $\begin{array}{c}156 \\
2 \mathrm{H}-3 \\
117-118 \\
\end{array}$ & $\begin{array}{c}156 \\
2 \mathrm{H}-3 \\
117-118 \\
\end{array}$ & $\begin{array}{c}156 \\
2 \mathrm{H}-3 \\
117-118 \\
\end{array}$ & $\begin{array}{c}156 \\
2 \mathrm{H}-3 \\
117-118 \\
\end{array}$ & $\begin{array}{c}158 \\
2 \mathrm{H}-5 \\
10-11\end{array}$ & $\begin{array}{c}158 \\
2 \mathrm{H}-5 \\
10-11\end{array}$ & $\begin{array}{c}158 \\
2 \mathrm{H}-5 \\
10-11\end{array}$ & $\begin{array}{c}158 \\
2 \mathrm{H}-5 \\
10-11\end{array}$ \\
\hline $\mathrm{SiO}_{2}$ & 75.04 & 74.96 & 75.04 & 75.67 & 75.27 & 73.86 & 74.33 & 74.47 & 74.11 & 74.03 & 74.77 & 79.48 & 79.14 & 79.36 & 80.05 \\
\hline $\mathrm{TiO}_{2}$ & 0.24 & 0.21 & 0.24 & 0.13 & 0.14 & 0.19 & 0.26 & 0.19 & 0.19 & 0.23 & 0.23 & 0.19 & 0 & 0 & 0 \\
\hline $\mathrm{Al}_{2} \mathrm{O}_{3}$ & 13.59 & 13.68 & 13.83 & 13.38 & 13.55 & 14.06 & 14.23 & 14.23 & 14.19 & 13.96 & 13.99 & 12.32 & 12.39 & 12.22 & 12.02 \\
\hline $\mathrm{FeO}^{*}$ & 1.87 & 2 & 2.18 & 2.05 & 2 & 2.44 & 2.3 & 2.33 & 2.52 & 2.36 & 2.53 & 0.76 & 0.86 & 0.87 & 0.78 \\
\hline $\mathrm{MnO}$ & 0 & 0 & 0 & 0 & 0 & 0 & 0 & 0 & 0 & 0 & 0 & 0 & 0 & 0 & 0 \\
\hline $\mathrm{MgO}$ & 0 & 0 & 0 & 0 & 0 & 0 & 0 & 0 & 0 & 0 & 0 & 0 & 0 & 0 & 0 \\
\hline $\mathrm{CaO}$ & 1.22 & 1.16 & 1.19 & 1.13 & 1.16 & 1.41 & 1.26 & 1.28 & 1.29 & 1.36 & 1.2 & 0.81 & 0.83 & 0.89 & 0.89 \\
\hline $\mathrm{K}_{2} \mathrm{O}$ & 3.55 & 3.59 & 3.44 & 3.49 & 3.64 & 3.74 & 3.81 & 3.72 & 3.8 & 3.81 & 3.74 & 2.87 & 2.96 & 2.88 & 2.81 \\
\hline $\mathrm{Na}_{2} \mathrm{O}$ & 4.49 & 4.4 & 3.72 & 4.16 & 4.25 & 4.31 & 3.79 & 3.77 & 3.9 & 4.24 & 3.54 & 3.57 & 3.83 & 3.78 & 3.46 \\
\hline Total & 98.28 & 104.2 & 99.15 & 100.12 & 100.57 & 101.21 & 101.53 & 98.88 & 101.68 & 100.83 & 98.13 & 101.72 & 97 & 97.36 & 95.1 \\
\hline
\end{tabular}

\begin{tabular}{|c|c|c|c|c|c|c|c|c|c|c|c|c|c|c|c|}
\hline $\begin{array}{l}\text { UNE number: } \\
\text { Core, section, } \\
\text { Interval }(\mathrm{cm}) \text { : }\end{array}$ & $\begin{array}{c}158 \\
2 \mathrm{H}-5 \\
10-11 \\
\end{array}$ & $\begin{array}{c}158 \\
2 \mathrm{H}-5 \\
10-11\end{array}$ & $\begin{array}{c}158 \\
2 \mathrm{H}-5 \\
10-11\end{array}$ & $\begin{array}{c}158 \\
2 \mathrm{H}-5 \\
10-11\end{array}$ & $\begin{array}{c}160 \\
5 \mathrm{H}-3 \\
67-68\end{array}$ & $\begin{array}{c}160 \\
5 \mathrm{H}-3 \\
67-68 \\
\end{array}$ & $\begin{array}{c}160 \\
5 \mathrm{H}-3 \\
67-68\end{array}$ & $\begin{array}{c}160 \\
5 \mathrm{H}-3 \\
67-68 \\
\end{array}$ & $\begin{array}{c}160 \\
5 \mathrm{H}-3 \\
67-68 \\
\end{array}$ & $\begin{array}{c}160 \\
5 \mathrm{H}-3 \\
67-68 \\
\end{array}$ & $\begin{array}{c}160 \\
5 \mathrm{H}-3 \\
67-68 \\
\end{array}$ & $\begin{array}{c}160 \\
5 \mathrm{H}-3 \\
67-68\end{array}$ & $\begin{array}{c}160 \\
5 \mathrm{H}-3 \\
67-68 \\
\end{array}$ & $\begin{array}{c}160 \\
5 \mathrm{H}-3 \\
67-68 \\
\end{array}$ & $\begin{array}{c}161 \\
5 \mathrm{H}-3 \\
132-133 \\
\end{array}$ \\
\hline $\mathrm{SiO}_{2}$ & 79.98 & 79.43 & 79.15 & 79.32 & 76.14 & 75.1 & 75.06 & 75.38 & 75.29 & 76.17 & 77.48 & 76.82 & 78.26 & 77.27 & 71.88 \\
\hline $\mathrm{TiO}_{2}^{-}$ & 0 & 0 & 0 & 0 & 0.28 & 0.2 & 0.37 & 0.33 & 0.41 & 0.26 & 0.24 & 0.32 & 0.28 & 0.23 & 0.16 \\
\hline $\mathrm{Al}_{2} \mathrm{O}_{3}$ & 12.23 & 12.34 & 12.2 & 12.2 & 13.98 & 14.07 & 14.09 & 14.09 & 13.28 & 13.35 & 13.51 & 13.81 & 13.38 & 13.56 & 17.07 \\
\hline $\mathrm{FeO}^{*}$ & 0.78 & 0.68 & 0.79 & 0.79 & 2.07 & 1.93 & 2.14 & 1.88 & 1.71 & 1.74 & 1.59 & 1.68 & 1.65 & 1.73 & 4.22 \\
\hline $\mathrm{MnO}$ & 0 & 0 & 0 & 0 & 0 & 0 & 0 & 0 & 0 & 0 & 0 & 0 & 0 & 0 & 0 \\
\hline $\mathrm{MgO}$ & 0 & 0 & 0 & 0 & 0 & 0 & 0 & 0 & 0 & 0 & 0 & 0 & 0 & 0 & 1.86 \\
\hline $\mathrm{CaO}$ & 0.77 & 0.86 & 0.86 & 0.84 & 2.01 & 1.95 & 1.91 & 1.88 & 1.27 & 1.12 & 1.11 & 1.24 & 1.01 & 1.14 & 0 \\
\hline $\mathrm{K}_{2} \mathrm{O}$ & 2.8 & 3.04 & 2.89 & 3.02 & 1.65 & 1.67 & 1.69 & 1.62 & 3.4 & 3.33 & 3.3 & 3.3 & 3.33 & 3.17 & 3.7 \\
\hline $\mathrm{Na}_{2} \mathrm{O}$ & 3.44 & 3.65 & 4.11 & 3.83 & 3.86 & 5.09 & 4.75 & 4.82 & 4.63 & 4.02 & 2.77 & 2.83 & 2.1 & 2.9 & 1.11 \\
\hline Total & 94.78 & 94.95 & 96.98 & 98.47 & 97.33 & 97.65 & 98.01 & 97.39 & 103.67 & 101.98 & 95.63 & 96.29 & 94.59 & 97.01 & 93.38 \\
\hline
\end{tabular}

\begin{tabular}{|c|c|c|c|c|c|c|c|c|c|c|c|c|c|c|c|}
\hline $\begin{array}{l}\text { UNE number: } \\
\text { Core, section, } \\
\text { Interval }(\mathrm{cm}) \text { : }\end{array}$ & $\begin{array}{c}162 \\
6 \mathrm{H}-2 \\
8-9\end{array}$ & $\begin{array}{c}163 \\
6 \mathrm{H}-3 \\
98-99 \\
\end{array}$ & $\begin{array}{c}163 \\
6 \mathrm{H}-3 \\
98-99 \\
\end{array}$ & $\begin{array}{c}163 \\
6 \mathrm{H}-3 \\
98-99 \\
\end{array}$ & $\begin{array}{c}163 \\
6 \mathrm{H}-3 \\
98-99 \\
\end{array}$ & $\begin{array}{c}164 \\
6 \mathrm{H}-6 \\
28-29 \\
\end{array}$ & $\begin{array}{c}165 \\
7 \mathrm{H}-5 \\
101-102 \\
\end{array}$ & $\begin{array}{c}165 \\
7 \mathrm{H}-5 \\
101-102\end{array}$ & $\begin{array}{c}165 \\
7 \mathrm{H}-5 \\
101-102 \\
\end{array}$ & $\begin{array}{c}168 \\
10 \mathrm{H}-1 \\
141-142 \\
\end{array}$ & $\begin{array}{c}168 \\
10 \mathrm{H}-1 \\
141-142 \\
\end{array}$ & $\begin{array}{c}169 \\
10 \mathrm{H}-5 \\
52-55 \\
\end{array}$ & $\begin{array}{c}169 \\
10 \mathrm{H}-5 \\
52-55\end{array}$ & $\begin{array}{c}169 \\
10 \mathrm{H}-5 \\
52-55\end{array}$ & $\begin{array}{c}169 \\
10 \mathrm{H}-5 \\
52-55 \\
\end{array}$ \\
\hline $\mathrm{SiO}_{2}$ & 69.34 & 68.93 & 69.23 & 69.52 & 70.83 & 61.81 & 70.4 & 79.4 & 74.62 & 61.18 & 53.48 & 70.42 & 70.95 & 71.75 & 72.26 \\
\hline $\mathrm{TiO}_{2}$ & 0.65 & 0.67 & 0.67 & 0.55 & 0.48 & 1.16 & 0.74 & 0.23 & 0.33 & 1.04 & 1.2 & 0.5 & 0.56 & 0.4 & 0.54 \\
\hline $\mathrm{Al}_{2} \mathrm{O}_{3}$ & 15.13 & 15.25 & 15.34 & 15.06 & 14.98 & 16.36 & 15.66 & 11.67 & 14.19 & 16.34 & 19.88 & 15.2 & 14.7 & 14.74 & 15.12 \\
\hline $\mathrm{FeO}^{*}$ & 4.26 & 4.43 & 4.36 & 4.37 & 3.74 & 7.55 & 3.67 & 1.47 & 1.99 & 7.8 & 8.62 & 3.8 & 3.72 & 3.39 & 3.77 \\
\hline $\mathrm{MnO}$ & 0 & 0 & 0 & 0 & 0 & 0 & 0 & 0 & 0 & 0 & 0 & 0 & 0 & 0 & 0 \\
\hline $\mathrm{MgO}$ & 0.27 & 0.37 & 0.35 & 0.39 & 0.16 & 1.44 & 0.44 & 0 & 0 & 1.87 & 2.17 & 0.18 & 0.21 & 0 & 0.15 \\
\hline $\mathrm{CaO}$ & 2.42 & 2.62 & 2.73 & 2.47 & 1.95 & 5.13 & 2.38 & 1.4 & 1.22 & 5.21 & 10.34 & 2.26 & 1.96 & 1.7 & 1.82 \\
\hline $\mathrm{K}_{2} \mathrm{O}$ & 2.85 & 2.87 & 2.85 & 2.76 & 3.63 & 2.06 & 2.87 & 3.17 & 4.41 & 1.9 & 0.87 & 2.94 & 3.23 & 3.26 & 3.12 \\
\hline $\mathrm{Na}_{2} \mathrm{O}$ & 5.07 & 4.85 & 4.47 & 4.88 & 4.25 & 4.49 & 3.85 & 2.65 & 3.24 & 4.67 & 3.43 & 4.69 & 4.67 & 4.75 & 3.21 \\
\hline Total & 99.42 & 99.89 & 100.31 & 95.89 & 97.34 & 100 & 100.01 & 99.99 & 100 & 103.13 & 102.15 & 103.72 & 104.25 & 96.73 & 95.33 \\
\hline
\end{tabular}

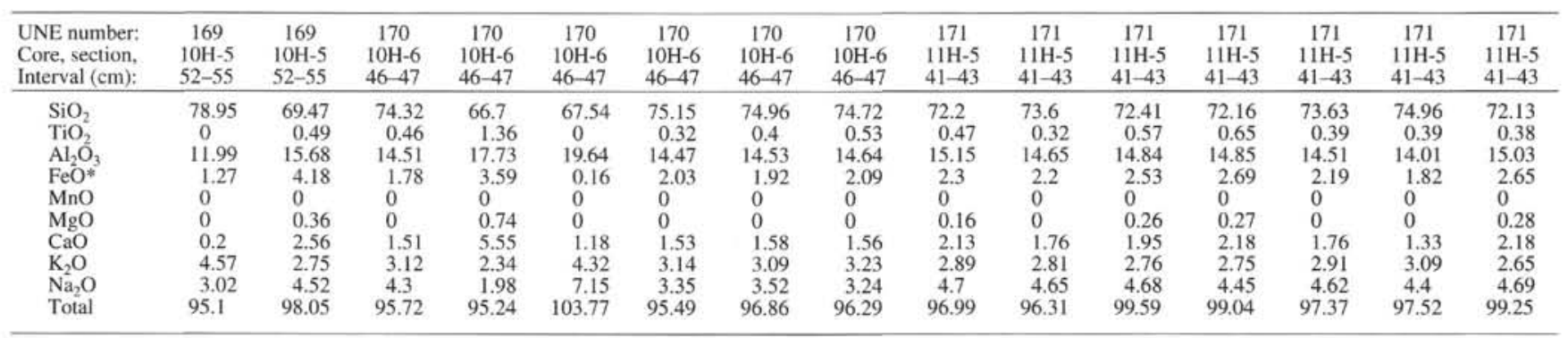

\begin{tabular}{|c|c|c|c|c|c|c|c|c|c|c|c|c|c|c|c|}
\hline $\begin{array}{l}\text { UNE number: } \\
\text { Core, section, } \\
\text { Interval }(\mathrm{cm}) \text { : }\end{array}$ & $\begin{array}{c}171 \\
11 \mathrm{H}-5 \\
41-43\end{array}$ & $\begin{array}{c}172 \\
11 \mathrm{H}-5 \\
89-91\end{array}$ & $\begin{array}{c}172 \\
11 \mathrm{H}-5 \\
89-91\end{array}$ & $\begin{array}{c}172 \\
11 \mathrm{H}-5 \\
89-91\end{array}$ & $\begin{array}{l}172 \\
11 \mathrm{H}-5 \\
89-91\end{array}$ & $\begin{array}{c}172 \\
11 \mathrm{H}-5 \\
89-91\end{array}$ & $\begin{array}{c}173 \\
13 \mathrm{H}-3 \\
7-8\end{array}$ & $\begin{array}{c}173 \\
13 \mathrm{H}-3 \\
7-8\end{array}$ & $\begin{array}{c}173 \\
13 \mathrm{H}-3 \\
7-8\end{array}$ & $\begin{array}{c}173 \\
13 \mathrm{H}-3 \\
7-8\end{array}$ & $\begin{array}{c}173 \\
13 \mathrm{H}-3 \\
7-8\end{array}$ & $\begin{array}{c}174 \\
13 \mathrm{H}-4 \\
97-98\end{array}$ & $\begin{array}{c}174 \\
13 \mathrm{H}-4 \\
97-98\end{array}$ & $\begin{array}{c}174 \\
13 \mathrm{H}-4 \\
97-98\end{array}$ & $\begin{array}{c}174 \\
13 \mathrm{H}-4 \\
97-98 \\
\end{array}$ \\
\hline $\mathrm{SiO}_{2}$ & 71.36 & 75.68 & 72.58 & 75.53 & 75.31 & 77.11 & 74.34 & 74.33 & 74.56 & 73.84 & 73.84 & 71.18 & 72.43 & 69.86 & 70.3 \\
\hline $\mathrm{TiO}_{2}$ & 0.56 & 0.39 & 0.58 & 0.33 & 0.52 & 0.28 & 0.18 & 0.24 & 0.2 & 0.35 & 0.38 & 0.41 & 0.26 & 0.55 & 0.49 \\
\hline $\mathrm{Al}_{2} \mathrm{O}_{3}$ & 15.32 & 13.43 & 14.34 & 13.56 & 13.77 & 12.92 & 14.69 & 14.32 & 14.63 & 14.53 & 14.44 & 15.23 & 15.25 & 15.59 & 15.55 \\
\hline $\mathrm{FeO}^{*}$ & 2.66 & 2.02 & 2.82 & 1.93 & 1.89 & 1.21 & 2.52 & 2.38 & 2.19 & 2.68 & 2.57 & 2.86 & 2.68 & 3.41 & 3.21 \\
\hline $\mathrm{MnO}$ & 0 & 0 & 0 & 0 & 0 & 0 & 0 & 0 & 0 & 0 & 0 & 0 & 0 & 0 & 0 \\
\hline $\mathrm{MgO}$ & 0.34 & 0 & 0.24 & 0 & 0 & 0 & 0 & 0 & 0 & 0 & 0 & 0.16 & 0 & 0.18 & 0.33 \\
\hline $\mathrm{CaO}$ & 2.26 & 1.17 & 2.03 & 1.2 & 1.23 & 0.73 & 1.15 & 1.16 & 1.13 & 1.24 & 1.17 & 1.51 & 1.28 & 2.05 & 1.97 \\
\hline $\mathrm{K}_{2} \mathrm{O}$ & 2.85 & 3.25 & 3.08 & 3.29 & 3.35 & 3.88 & 4.28 & 4.1 & 4.21 & 4.24 & 4.32 & 3.29 & 3.35 & 3.39 & 3.16 \\
\hline $\mathrm{Na}_{2} \mathrm{O}$ & 4.66 & 4.06 & 4.31 & 4.16 & 3.93 & 3.87 & 2.84 & 3.45 & 3.09 & 3.13 & 3.29 & 5.37 & 4.74 & 4.97 & 5.01 \\
\hline Total & 99.14 & 102.55 & 98.7 & 96.52 & 96.79 & 97 & 95.44 & 96.93 & 95.97 & 96.92 & 98.18 & 95.87 & 93.95 & 95.44 & 95.94 \\
\hline
\end{tabular}


Table 2 (continued).

\begin{tabular}{|c|c|c|c|c|c|c|c|c|c|c|c|c|c|c|c|}
\hline $\begin{array}{l}\text { UNE number: } \\
\text { Core, section, } \\
\text { Interval }(\mathrm{cm}) \text { : }\end{array}$ & $\begin{array}{c}175 \\
14 \mathrm{H}-3 \\
97-98 \\
\end{array}$ & $\begin{array}{c}175 \\
14 \mathrm{H}-3 \\
97-98 \\
\end{array}$ & $\begin{array}{c}175 \\
14 \mathrm{H}-3 \\
97-98 \\
\end{array}$ & $\begin{array}{c}175 \\
14 \mathrm{H}-3 \\
97-98 \\
\end{array}$ & $\begin{array}{c}175 \\
14 \mathrm{H}-3 \\
97-98 \\
\end{array}$ & $\begin{array}{c}175 \\
14 \mathrm{H}-3 \\
97-98\end{array}$ & $\begin{array}{c}175 \\
14 \mathrm{H}-3 \\
97-98 \\
\end{array}$ & $\begin{array}{c}175 \\
14 \mathrm{H}-3 \\
97-98 \\
\end{array}$ & $\begin{array}{c}175 \\
14 \mathrm{H}-3 \\
97-98 \\
\end{array}$ & $\begin{array}{c}175 \\
14 \mathrm{H}-3 \\
97-98 \\
\end{array}$ & $\begin{array}{c}177 \\
16 X-3 \\
104-105\end{array}$ & $\begin{array}{c}177 \\
16 X-3 \\
104-105 \\
\end{array}$ & $\begin{array}{c}177 \\
16 X-3 \\
104-105 \\
\end{array}$ & $\begin{array}{c}177 \\
16 X-3 \\
104-105 \\
\end{array}$ & $\begin{array}{c}177 \\
16 \times-3 \\
104-105 \\
\end{array}$ \\
\hline $\mathrm{SiO}_{2}$ & 58.48 & 59.18 & 58.16 & 62.87 & 67.21 & 57.22 & 58.03 & 59.95 & 59.7 & 58.49 & 75.2 & 75.29 & 72.24 & 65.31 & 75.43 \\
\hline $\mathrm{TiO}_{2}$ & 0.96 & 1.3 & 1.16 & 1.03 & 0.48 & 1.29 & 1.2 & 1.24 & 1.03 & 1.2 & 0.27 & 0.35 & 0.57 & 1.06 & 0.37 \\
\hline $\mathrm{Al}_{2} \hat{\mathrm{O}}_{3}$ & 17.85 & 15.72 & 17.6 & 16.15 & 18.73 & 16.03 & 16.28 & 16.82 & 16.56 & 16.13 & 13.65 & 13.78 & 14.7 & 15.74 & 13.78 \\
\hline $\mathrm{FeO}^{*}$ & 7.04 & 9.66 & 8.22 & 6.46 & 1.81 & 10.31 & 9.84 & 7.91 & 8.47 & 9.34 & 2.29 & 2.32 & 3.36 & 5.56 & 2.4 \\
\hline $\mathrm{MnO}$ & 0 & 0 & 0 & 0 & 0 & 0 & 0 & 0 & 0 & 0 & 0 & 0 & 0 & 0 & 0 \\
\hline $\mathrm{MgO}$ & 2.18 & 2.51 & 2.14 & 1.51 & 0 & 2.86 & 2.75 & 2.01 & 2.3 & 2.54 & 0 & 0 & 0.4 & 1.52 & 0 \\
\hline $\mathrm{CaO}$ & 7.99 & 6.64 & 7.44 & 4.93 & 4.19 & 7.27 & 7.02 & 6.11 & 6.63 & 6.79 & 1.55 & 1.54 & 2.65 & 4.64 & 1.73 \\
\hline $\mathrm{K}_{2} \mathrm{O}$ & 0.95 & 1.46 & 1.3 & 2.09 & 2.24 & 1.28 & 1.33 & 1.56 & 1.44 & 1.46 & 3.72 & 3.73 & 3.29 & 2.37 & 3.33 \\
\hline $\mathrm{Na}_{2} \mathrm{O}$ & 4.55 & 3.54 & 3.98 & 4.96 & 5.34 & 3.76 & 3.55 & 4.39 & 3.88 & 4.06 & 3.31 & 3 & 2.79 & 3.81 & 2.97 \\
\hline Total & 104.66 & 102.65 & 101.09 & 101.08 & 101.3 & 102.12 & 102.34 & 101.84 & 100.34 & 102.49 & 103.04 & 95.52 & 96.71 & 99.58 & 95.48 \\
\hline
\end{tabular}

\begin{tabular}{|c|c|c|c|c|c|c|c|c|c|c|c|c|c|c|c|}
\hline $\begin{array}{l}\text { UNE number: } \\
\text { Core, section, } \\
\text { Interval }(\mathrm{cm}) \text { : }\end{array}$ & $\begin{array}{c}177 \\
16 X-3 \\
104-105 \\
\end{array}$ & $\begin{array}{c}177 \\
16 X-3 \\
104-105\end{array}$ & $\begin{array}{c}177 \\
16 X-3 \\
104-105\end{array}$ & $\begin{array}{c}177 \\
16 X-3 \\
104-105\end{array}$ & $\begin{array}{c}177 \\
16 X-3 \\
104-105\end{array}$ & $\begin{array}{c}178 \\
24 \mathrm{H}-2 \\
24-25\end{array}$ & $\begin{array}{c}178 \\
24 \mathrm{H}-2 \\
24-25\end{array}$ & $\begin{array}{c}178 \\
24 \mathrm{H}-2 \\
24-25\end{array}$ & $\begin{array}{c}179 \\
25 \mathrm{H}-6 \\
97-98\end{array}$ & $\begin{array}{c}179 \\
25 \mathrm{H}-6 \\
97-98\end{array}$ & $\begin{array}{c}179 \\
25 \mathrm{H}-6 \\
97-98\end{array}$ & $\begin{array}{c}179 \\
25 \mathrm{H}-6 \\
97-98\end{array}$ & $\begin{array}{c}179 \\
25 \mathrm{H}-6 \\
97-98\end{array}$ & $\begin{array}{c}179 \\
25 \mathrm{H}-6 \\
97-98\end{array}$ & $\begin{array}{c}179 \\
25 \mathrm{H}-6 \\
97-98\end{array}$ \\
\hline $\mathrm{SiO}_{2}$ & 75.92 & 76.19 & 75.74 & 74.96 & 75.77 & 65.52 & 64.01 & 53.82 & 72.25 & 72.43 & 58.67 & 70.89 & 71.82 & 73 & 72.49 \\
\hline $\mathrm{TiO}_{2}$ & 0.25 & 0.31 & 0.33 & 0.79 & 0.46 & 1.03 & 1.34 & 2.58 & 0.52 & 0.48 & 1.73 & 0.74 & 0.75 & 0.45 & 0.59 \\
\hline $\mathrm{Al}_{2} \mathrm{O}_{3}$ & 13.68 & 13.79 & 13.93 & 12.8 & 13.7 & 15.4 & 15.76 & 16.36 & 14.29 & 14.19 & 15.73 & 13.98 & 13.97 & 14.33 & 14.4 \\
\hline $\mathrm{FeO}^{*}$ & 2.39 & 2.25 & 2.19 & 3.28 & 2.22 & 5.86 & 6.39 & 11.08 & 3.57 & 3.49 & 9.39 & 4.1 & 4.19 & 3.59 & 3.45 \\
\hline $\mathrm{MnO}$ & 0 & 0 & 0 & 0 & 0 & 0.19 & 0 & 0 & 0 & 0 & 0 & 0 & 0 & 0 & 0 \\
\hline $\mathrm{MgO}$ & 0 & 0 & 0 & 0.17 & 0 & 0.89 & 1.56 & 3.72 & 0.3 & 0.33 & 2.93 & 0.59 & 0.34 & 0 & 0.21 \\
\hline $\mathrm{CaO}$ & 1.48 & 1.45 & 1.5 & 1.57 & 1.49 & 3.6 & 4.3 & 8.56 & 2.05 & 2.02 & 7.09 & 2.3 & 2.01 & 1.86 & 1.97 \\
\hline $\mathrm{K}_{2} \mathrm{O}$ & 3.63 & 3.62 & 3.64 & 3.79 & 3.64 & 2.34 & 2.2 & 1 & 1.91 & 1.88 & 1.2 & 1.95 & 1.97 & 1.95 & 2 \\
\hline $\mathrm{Na}_{2} \mathrm{O}$ & 2.65 & 2.4 & 2.67 & 2.64 & 2.72 & 5.18 & 4.44 & 2.87 & 5.12 & 5.19 & 3.25 & 5.45 & 4.95 & 4.83 & 4.89 \\
\hline Total & 97 & 95.55 & 96.6 & 96.52 & 97.04 & 103.42 & 100.52 & 104.04 & 103.02 & 101.04 & 101.74 & 100.61 & 99.35 & 97.11 & 97.52 \\
\hline
\end{tabular}

\begin{tabular}{lccccccccc}
\hline UNE number: & 179 & 179 & 180 & 180 & 180 & 180 & 180 & 180 & 180 \\
Core, section, & $25 \mathrm{H}-6$ & $25 \mathrm{H}-6$ & $28 \mathrm{H}-5$ & $28 \mathrm{H}-5$ & $28 \mathrm{H}-5$ & $28 \mathrm{H}-5$ & $28 \mathrm{H}-5$ & $28 \mathrm{H}-5$ & $28 \mathrm{H}-5$ \\
Interval $(\mathrm{cm}):$ & $97-98$ & $97-98$ & $22-23$ & $22-23$ & $22-23$ & $22-23$ & $22-23$ & $22-23$ & $22-23$ \\
\hline $\mathrm{SiO}_{2}$ & 72.27 & 56.14 & 75.47 & 73.46 & 75.86 & 75.84 & 76.13 & 76.32 & 69.88 \\
$\mathrm{TiO}_{2}$ & 0.55 & 1.87 & 0.26 & 0.37 & 0.24 & 0.21 & 0.31 & 0.38 & 1.11 \\
$\mathrm{Al}_{2} \mathrm{O}_{3}$ & 14.34 & 15.54 & 13.46 & 14.82 & 13.83 & 13.94 & 13.64 & 13.69 & 12.88 \\
$\mathrm{FeO}^{*}$ & 3.58 & 11.16 & 1.8 & 2.5 & 1.87 & 1.78 & 1.71 & 1.7 & 6.82 \\
$\mathrm{MnO}$ & 0 & 0 & 0 & 0 & 0 & 0 & 0 & 0 & 0 \\
$\mathrm{MgO}$ & 0.3 & 2.72 & 0 & 0 & 0 & 0 & 0 & 0 & 0.69 \\
$\mathrm{CaO}$ & 2.05 & 8.74 & 0.87 & 1.7 & 1 & 0.99 & 0.94 & 0.91 & 1.22 \\
$\mathrm{~K}_{2} \mathrm{O}$ & 1.86 & 0.91 & 4.18 & 3.71 & 4.04 & 4.09 & 4.07 & 4.18 & 2.49 \\
$\mathrm{Na} 2$ & 5.05 & 2.93 & 3.97 & 3.44 & 3.16 & 3.14 & 3.21 & 2.82 & 4.9 \\
$\mathrm{Total}$ & 98.38 & 100.01 & 98.62 & 96.59 & 92.02 & 95.4 & 97.01 & 95.64 & 101.46 \\
& & & & & & & & &
\end{tabular}

Notes: Major elements reported as wt\% oxides. UNE number $=$ ash-layer number analyzed at the University of New England $($ see Table 1). Total $=$ original analytical total. Individual oxide values sum to $100 \%$. Zero values indicate that the element abundances are less than the detection limit of EDS. 
Table 3. Bulk major and trace element analyses of ash layers from Hole 887A.

\begin{tabular}{|c|c|c|c|c|c|c|c|c|c|c|c|c|c|c|c|c|}
\hline $\begin{array}{l}\text { UNE number: } \\
\text { Core, section: } \\
\text { Interval }(\mathrm{cm}) \text { : }\end{array}$ & $\begin{array}{c}160 \\
5 \mathrm{H}-3 \\
67-68 \\
\end{array}$ & $\begin{array}{c}163 \\
6 \mathrm{H}-3 \\
98-99 \\
\end{array}$ & $\begin{array}{c}164 \\
6 \mathrm{H}-6 \\
28-29 \\
\end{array}$ & $\begin{array}{c}165 \\
7 \mathrm{H}-5 \\
101-102 \\
\end{array}$ & $\begin{array}{c}168 \\
10 \mathrm{H}-1 \\
141-142\end{array}$ & $\begin{array}{c}169 \\
10 \mathrm{H}-5 \\
52-55\end{array}$ & $\begin{array}{c}170 \\
10 \mathrm{H}-6 \\
46-47\end{array}$ & $\begin{array}{c}171 \\
11 \mathrm{H}-5 \\
41-43 \\
\end{array}$ & $\begin{array}{c}172 \\
11 \mathrm{H}-5 \\
89-91\end{array}$ & $\begin{array}{c}173 \\
13 \mathrm{H}-3 \\
7-8\end{array}$ & $\begin{array}{c}174 \\
13 \mathrm{H}-4 \\
97-98\end{array}$ & $\begin{array}{c}175 \\
14 \mathrm{H}-3 \\
63-64\end{array}$ & $\begin{array}{c}177 \\
16 X-3 \\
104-105 \\
\end{array}$ & $\begin{array}{c}178 \\
24 \mathrm{H}-2 \\
24-25\end{array}$ & $\begin{array}{c}179 \\
25 \mathrm{H}-6 \\
121-122 \\
\end{array}$ & $\begin{array}{c}180 \\
28 \mathrm{H}-5 \\
22-23\end{array}$ \\
\hline $\begin{array}{l}\mathrm{SiO}_{2} \\
\mathrm{TiO}_{2} \\
\mathrm{Al}_{2} \mathrm{O}_{3} \\
\mathrm{FeO}^{*} \\
\mathrm{MnO} \\
\mathrm{MgO} \\
\mathrm{CaO} \\
\mathrm{K}_{2} \mathrm{O} \\
\mathrm{Na}_{2} \mathrm{O}\end{array}$ & $\begin{array}{c}76.39 \\
0.29 \\
13.7 \\
1.8 \\
0 \\
0 \\
1.43 \\
2.69 \\
3.7\end{array}$ & $\begin{array}{r}69.63 \\
0.59 \\
15.16 \\
4.23 \\
0 \\
0.32 \\
2.44 \\
3.03 \\
4.61\end{array}$ & $\begin{array}{r}61.81 \\
1.16 \\
16.36 \\
7.55 \\
0 \\
1.44 \\
5.13 \\
2.06 \\
4.49\end{array}$ & $\begin{array}{r}74.81 \\
0.43 \\
13.84 \\
2.38 \\
0 \\
0.15 \\
1.67 \\
3.48 \\
3.25\end{array}$ & $\begin{array}{r}57.33 \\
1.12 \\
18.11 \\
8.21 \\
0 \\
2.02 \\
7.78 \\
1.39 \\
4.05\end{array}$ & $\begin{array}{c}72.3 \\
0.42 \\
14.57 \\
3.36 \\
0 \\
0.15 \\
1.75 \\
3.31 \\
4.14\end{array}$ & $\begin{array}{r}72.23 \\
0.51 \\
15.92 \\
1.93 \\
0 \\
0.12 \\
2.15 \\
3.21 \\
3.92\end{array}$ & $\begin{array}{c}72.81 \\
0.47 \\
14.8 \\
2.38 \\
0 \\
0.16 \\
1.94 \\
2.84 \\
4.61\end{array}$ & $\begin{array}{c}75.24 \\
0.42 \\
13.6 \\
1.97 \\
0 \\
0.05 \\
1.27 \\
3.37 \\
4.07\end{array}$ & $\begin{array}{r}74.18 \\
0.27 \\
14.52 \\
2.47 \\
0 \\
0 \\
1.17 \\
4.23 \\
3.16\end{array}$ & $\begin{array}{c}70.94 \\
0.43 \\
15.41 \\
3.04 \\
0 \\
0.17 \\
1.7 \\
3.3 \\
5.02\end{array}$ & $\begin{array}{c}59.93 \\
1.09 \\
16.79 \\
7.91 \\
0 \\
2.08 \\
6.5 \\
1.51 \\
4.2\end{array}$ & $\begin{array}{c}74.21 \\
0.48 \\
13.96 \\
2.83 \\
0 \\
0.21 \\
1.96 \\
3.48 \\
2.9\end{array}$ & $\begin{array}{r}61.12 \\
1.65 \\
15.84 \\
7.78 \\
0.06 \\
2.06 \\
5.49 \\
1.85 \\
4.16\end{array}$ & $\begin{array}{r}68.88 \\
0.85 \\
14.53 \\
5.17 \\
0 \\
0.86 \\
3.34 \\
1.74 \\
4.63\end{array}$ & $\begin{array}{c}74.71 \\
0.41 \\
13.75 \\
2.6 \\
0 \\
0.1 \\
1.09 \\
3.82 \\
3.52\end{array}$ \\
\hline Sc & 16 & 15 & 13 & 13 & 24 & 14 & 8 & 14 & 12 & 12 & 13 & 22 & 11 & 17 & 18 & 10 \\
\hline V & 44 & 38 & 89 & 108 & 164 & 40 & 52 & 34 & 37 & 32 & 46 & 177 & 12 & 44 & 72 & 29 \\
\hline $\mathrm{Cr}$ & 14 & 8 & 46 & 60 & 9 & 7 & 37 & 7 & 7 & 9 & 7 & 11 & & & & s \\
\hline Co & 3 & 7 & 11 & 17 & 17 & 5 & & 4 & 3 & 5 & 7 & 37 & 5 & 8 & 8 & 5 \\
\hline $\mathrm{Ni}$ & 9 & 12 & 25 & 32 & 16 & 6 & & 10 & 7 & 10 & 11 & 28 & 2 & 11 & 8 & 5 \\
\hline $\mathrm{Cu}$ & 22 & 24 & 14 & 13 & 40 & 27 & & 13 & 30 & 47 & 16 & 40 & 7 & 22 & 16 & 11 \\
\hline $\mathrm{Zn}$ & 36 & 56 & 29 & 34 & 72 & 48 & & 45 & 42 & 37 & 48 & 60 & 30 & 58 & 54 & 31 \\
\hline $\mathrm{Ga}$ & 14 & 19 & 12 & 13 & 21 & 18 & 4 & 17 & 17 & 17 & 17 & 18 & 15 & 19 & 18 & 15 \\
\hline $\mathrm{Ge}$ & 1 & 1 & 1 & 1 & 1 & 1 & & 1 & 1 & 1 & 1 & 1 & 1 & 1 & 1 & 1 \\
\hline $\mathrm{Rb}$ & 26.8 & 59.7 & 39 & 38.8 & 33.2 & 58.3 & 23.3 & 56.3 & 62.7 & 91.3 & 46.6 & 22.8 & 69.7 & 41.1 & 20.7 & 68.9 \\
\hline $\mathrm{Sr}$ & 259 & 231.4 & 343.9 & 348.4 & 400.3 & 201.5 & 247.2 & 223.8 & 197.5 & 175.8 & 232 & 428.6 & 200.7 & 244.7 & 254.5 & 161.5 \\
\hline $\mathrm{Y}$ & 35.6 & 54.4 & 14.7 & 16 & 42.1 & 53.2 & 5.4 & 47.9 & 47.7 & 48.9 & 41.2 & 30.6 & 44.3 & 48.5 & 42.7 & 34.7 \\
\hline $\mathrm{Zr}$ & 145.6 & 295.7 & 47 & 53.3 & 177.8 & 294.7 & 122.3 & 252.1 & 271.1 & 362.9 & 239.3 & 142.2 & 325.5 & 271.1 & 208.6 & 325.7 \\
\hline $\mathrm{Nb}$ & 3.8 & 10.3 & 5.4 & 6.1 & 5.7 & 8.9 & 4.1 & 11.4 & 12.3 & 10.1 & 6.8 & 4.7 & 9 & 12.7 & 10.3 & 11.7 \\
\hline Cs & 0.9 & 3.5 & 1.2 & 1.3 & 1.6 & 3.1 & 0.7 & 2.3 & 2.6 & 4.8 & 2 & 0.9 & 4 & 2.1 & 0.9 & 3.1 \\
\hline $\mathrm{Ba}$ & 459.6 & 743.9 & 602.9 & 576.2 & 629.9 & 862.3 & 292.3 & 713.9 & 683.7 & 847.8 & 643.8 & 428 & 895.9 & 526.3 & 308.9 & 628.2 \\
\hline $\mathrm{La}$ & 10.53 & 22.57 & 14.54 & 15.76 & 16.76 & 21.51 & 9.2 & 20.5 & 20.72 & 31.45 & 17.99 & 12.56 & 25.24 & 19.87 & 15.45 & 22.04 \\
\hline $\mathrm{Ce}$ & 24.74 & 50.3 & 29.37 & 31.51 & 38.4 & 48.25 & 25.51 & 45.05 & 45.33 & 66.42 & 41.02 & 29.41 & 54.26 & 44.19 & 35.34 & 47.3 \\
\hline Pr & 3.39 & 6.8 & 3.59 & 3.76 & 5.48 & 6.97 & 2.93 & 6.38 & 6.11 & 8.44 & 5.88 & 4.26 & 7.57 & 6.51 & 5.3 & 6.36 \\
\hline $\mathrm{Nd}$ & 16.12 & 31.83 & 15.15 & 15.63 & 26.55 & 30.65 & 8.16 & 27.58 & 26.58 & 34.35 & 26.12 & 19.35 & 31.43 & 29.66 & 24.61 & 25.75 \\
\hline $\mathrm{Sm}$ & 4.34 & 7.75 & 3.19 & 3.32 & 6.72 & 7.46 & 2.11 & 6.66 & 6.35 & 7.53 & 6.3 & 4.88 & 7.17 & 7.23 & 6.22 & 5.53 \\
\hline $\mathrm{Eu}$ & 1.35 & 2.21 & 1.29 & 1.36 & 2.28 & 2.18 & 0.65 & 2.11 & 1.89 & 1.9 & 1.95 & 1.69 & 2.05 & 2.13 & 1.92 & 1.4 \\
\hline Gd & 4.15 & 8.2 & 3.7 & 4.18 & 6.38 & 8.27 & 1.19 & 7.62 & 7.02 & 8.7 & 6.54 & 4.73 & 9.13 & 7.96 & 7 & 7.14 \\
\hline $\mathrm{Tb}$ & 0.75 & 1.25 & 0.44 & 0.47 & 1.06 & 1.23 & 0.17 & 1.1 & 1.05 & 1.17 & 0.99 & 0.77 & 1.14 & 1.16 & 1.02 & 0.84 \\
\hline Dy & 4.64 & 7.59 & 2.45 & 2.58 & 6.04 & 7.69 & 1.02 & 6.94 & 6.56 & 7.09 & 6.08 & 4.74 & 6.82 & 6.89 & 6.17 & 4.97 \\
\hline Dy & 5.17 & 8.09 & 2.47 & 2.53 & 6.39 & 8.03 & 1.76 & 7.3 & 6.95 & 7.43 & 6.4 & 5.11 & 6.91 & 7.15 & 6.38 & 4.99 \\
\hline Ho & 1.14 & 1.77 & 0.51 & 0.53 & 1.39 & 1.76 & 0.35 & 1.59 & 1.53 & 1.58 & 1.37 & 1.08 & 1.47 & 1.51 & 1.38 & 1.06 \\
\hline $\mathrm{Er}$ & 3.02 & 4.63 & 1.35 & 1.43 & 3.61 & 4.49 & 0.76 & 4.01 & 3.91 & 4.12 & 3.52 & 2.68 & 3.86 & 3.95 & 3.58 & 2.89 \\
\hline $\mathrm{Tm}$ & 0.54 & 0.79 & 0.21 & 0.23 & 0.59 & 0.77 & 0.14 & 0.68 & 0.67 & 0.7 & 0.59 & 0.45 & 0.64 & 0.65 & 0.58 & 0.48 \\
\hline $\mathrm{Yb}$ & 3.34 & 5.09 & 1.33 & 1.47 & 3.74 & 5.09 & 1.09 & 4.45 & 4.33 & 4.49 & 3.86 & 2.87 & 4.22 & 4.26 & 3.96 & 3.28 \\
\hline $\mathrm{Lu}$ & 0.5 & 0.78 & 0.19 & 0.22 & 0.56 & 0.86 & 0.14 & 0.75 & 0.75 & 0.77 & 0.65 & 0.47 & 0.7 & 0.68 & 0.6 & 0.53 \\
\hline $\mathrm{Hf}$ & 3.6 & 7.25 & 1.1 & 1.25 & 4.42 & 7.6 & 1.58 & 6.5 & 7.04 & 9,71 & 6.31 & 3.86 & 8.24 & 6.5 & 4.98 & 7.58 \\
\hline $\mathrm{Ta}$ & 0.3 & 0.77 & 0.38 & 0.42 & 0.44 & 0.65 & 0.35 & 0.77 & 0.84 & 0.78 & 0.52 & 0.38 & 0.7 & 0.83 & 0.7 & 0.86 \\
\hline $\mathrm{Pb}$ & 5.98 & 14.6 & 6.81 & 6.08 & 10.24 & 25.83 & 3.95 & 18.93 & 20.14 & 22.68 & 17.12 & 11.32 & 23.07 & 13 & 7.04 & 13.74 \\
\hline Th & 1.33 & 5.92 & 2.74 & 2.77 & 1.95 & 6.19 & 0.5 & 5.58 & 6.35 & 14.91 & 5.66 & 2.03 & 9.67 & 3.77 & 1.62 & 6.63 \\
\hline $\mathrm{U}$ & 0.55 & 2.32 & 0.83 & 0.79 & 0.52 & 3.68 & 0.58 & 3.23 & 3.64 & 7.03 & 3.14 & 1.1 & 4.72 & 1.76 & 0.8 & 2.88 \\
\hline
\end{tabular}

Note: UNE number = ash-layer number analyzed at the University of New England (see Table 1). Major elements are averages of individual shard analyses from the same layer. Major elements reported as wt\% oxides and trace elements as parts per million. All Fe reported as $\mathrm{FeO} *$. 


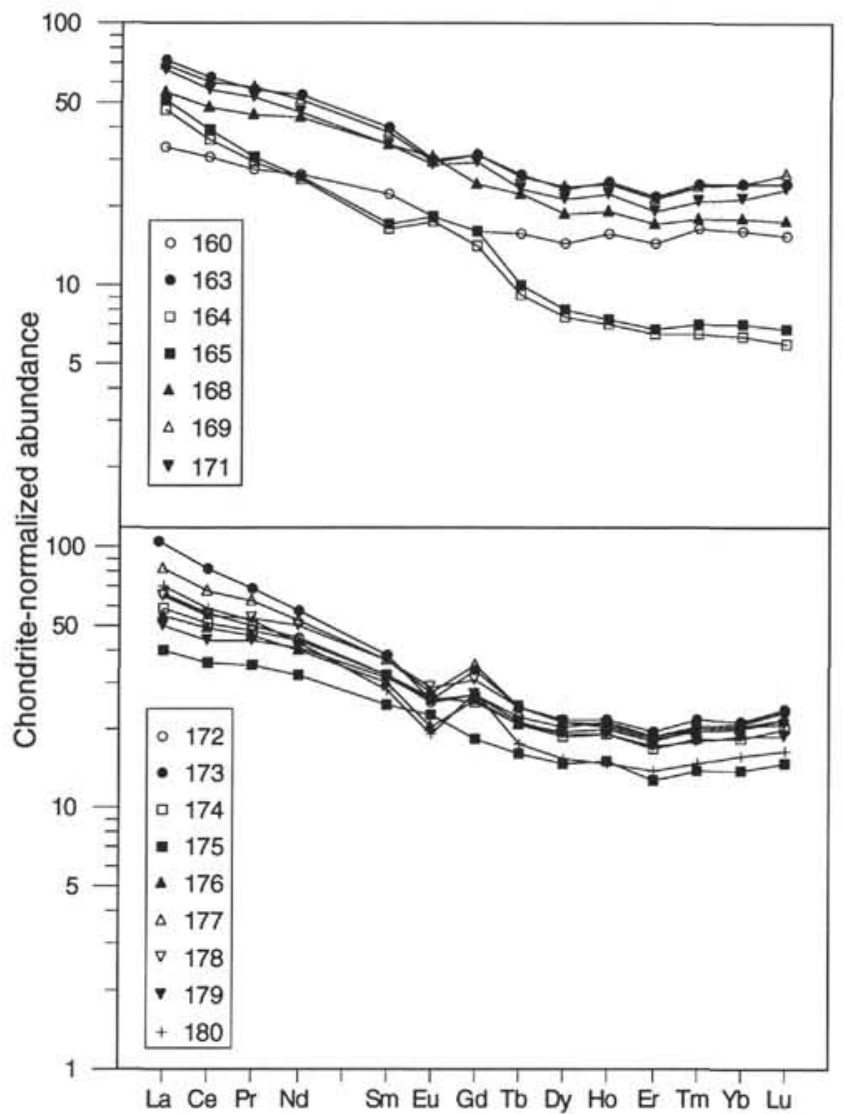

Figure 5. Chondrite-normalized rare earth element abundances for bulk samples of ash layers from Hole 887A. UNE numbers are shown for individual layer symbols (see Table 1).

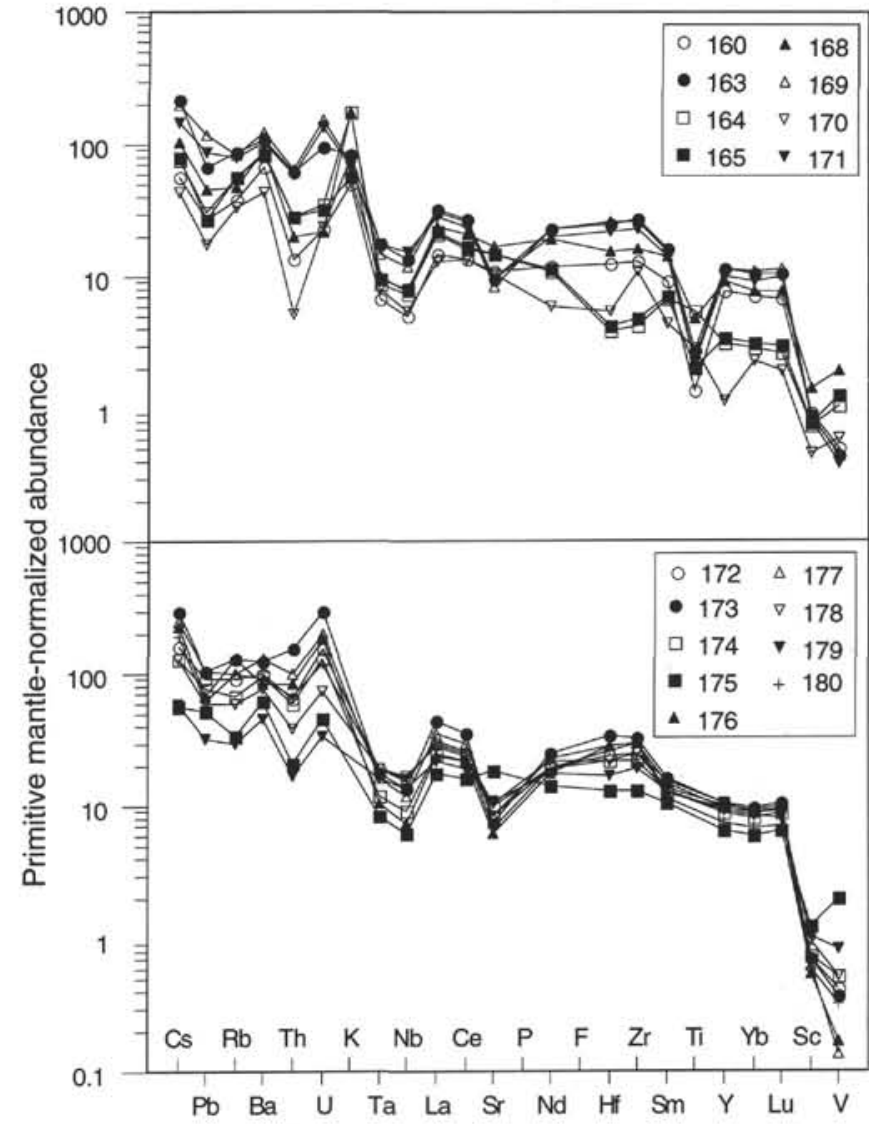

Figure 6. Primitive mantle-normalized trace element abundances for bulk samples of ash layers from Hole 887A. UNE numbers are shown for individual layer symbols. Normalizing values from Sun and McDonough (1989). 